\title{
MICRO-ESTIMATION OF PLASMA IRON WITH ORTHOTOLIDINE
}

\author{
BY \\ O. E. BUDTZ-OLSEN \\ From the Department of Physiology and Pharmacology, University of Capetown
}

(RECEIVED FOR PUBLICATION JUNE 22, 1950)

The estimation of plasma or serum iron and of the iron-binding capacity of the plasma is becoming an increasingly important diagnostic procedure for the clinical haematologist (Rath and Finch, 1949; Cartwright and Wintrobe, 1949). Current methods for this estimation are time-consuming and difficult to carry out, and their use has therefore been confined mainly to the research laboratory. The test to be described is so simple that it can be used as a routine in any laboratory. It overcomes in a reliable way the difficulty of rendering the glassware iron-free, and it requires less than $1 \mathrm{ml}$. of plasma for a double estimation, an important consideration in work on children and small animals.

$o$-Tolidine (4, 4'-diamino-3, 3'-dimethyl-diphenyl) was first used for the demonstration of blood in the urine by Ruttan and Hardisty in 1912. The procedure has lately been thoroughly standardized by Zwarenstein (1949). In carrying out the test for blood in the urine it was soon found that the slightest contamination with iron produced false positive results. From this observation the method for the plasma iron estimation was developed.

The following reagents are required.

\section{Reagents}

\section{Glass-distilled Water.}

2. Standard Iron Solution.-Wong's solution is convenient.

Crystallized ferrous ammonium sulphate (dried to constant weight), $0.7 \mathrm{~g}$., is dissolved in about $50 \mathrm{ml}$. of glass-distilled water. To it is added $20 \mathrm{ml}$. of $10 \%$ iron-free sulphuric acid, the solution is warmed slightly, and then is added decinormal solution of potassium permanganate to oxidize the ferrous salt completely. It is diluted to $1,000 \mathrm{ml}$. with water. One ml. contains $100 \mu \mathrm{g}$. of iron.

The working solution is prepared by diluting $1 \mathrm{ml}$. of the standard solution to $100 \mathrm{ml}$. with water, so that $1 \mathrm{ml}$. contains $1 \mu \mathrm{g}$. of iron.

3. Trichloracetic Acid Solution, 50\% v/v.-Trichloracetic acid is mixed with excess concentrated sulphuric acid and distilled in an all-glass distillation apparatus into a known volume of water in a measuring cylinder. After the distillation the volume is adjusted with water to make a $50 \% \mathrm{v} / \mathrm{v}$ solution.

4. o-Tolidine Solution $(0.05 \% \mathrm{w} / \mathrm{v})$. - Pure (nearly white) $o$-tolidine hydrochloride, $0.5 \mathrm{~g}$., is dissolved in $1,000 \mathrm{ml}$. of water. The solution becomes slightly brownish on standing, but retains its effectiveness for months, especially if stored in the dark in a refrigerator. 
During this investigation the laboratory ran out of pure $o$-tolidine hydrochloride and the sulphate had to be substituted temporarily. This substance is less soluble, and in a $0.05 \%$ $\mathrm{w} / \mathrm{v}$ solution a precipitate remains. However, if the solution is kept in a tall narrow container the precipitate settles firmly on the bottom and the supernatant fluid is as effective as the hydrochloride solution.

5. Acid-peroxide Solution.-Equal volumes of glass-distilled glacial acetic acid and 3\% hydrogen peroxide, freshly diluted from $30 \%$, are mixed. This stock solution lasts for many months. The working solution is prepared by diluting $2 \mathrm{ml}$. of stock solution to $10 \mathrm{ml}$. with water. It was found that different batches of alleged $30 \%$ hydrogen peroxide differed markedly in their true strength. It may therefore be necessary to adjust the working solution in such a way that in carrying out the test the blank remains nearly colourless and the colour with known amounts of iron falls inside the best working range of the colorimeter used.

\section{Cleaning of Glassware}

All glassware used in the test is cleaned in ordinary bichromate cleaning fluid and rinsed in tap water and glass-distilled water. Any trace of iron left is now removed by filling the glassware with $o$-tolidine solution, adding a few drops of trichloracetic acid and a few drops of acid-peroxide, and keeping the glassware in a boiling water bath for about 10 minutes. The glassware is then drained and is ready for use. The ordinary test-tubes employed in the test can be used again after each estimation simply by draining and without further cleaning. Before this procedure was adopted it was found impossible to obtain reproducible results. With this cleaning method the results have been consistently accurate with known amounts of iron.

For each solution a separate pipette is kept in a holster made of a large piece of filter paper rolled into a tube.

\section{Procedure}

Contamination of the blood is avoided by collecting it without the use of a syringe. An intravenous steel needle is inserted into a convenient vein and about $0.5 \mathrm{ml}$. of blood is allowed to run away. About $3 \mathrm{ml}$. of blood is run into an $o$-tolidine-cleaned Kahn tube containing a drop of heparin solution. The solution is mixed, and centrifuged at 3,000 r.p.m. for 30 minutes.

Plasma, $0.25 \mathrm{ml}$., is transferred into one Kahn tube and $0.50 \mathrm{ml}$. into another, and $1.75 \mathrm{ml}$. of water to the first tube and $1.50 \mathrm{ml}$. to the other is added.

To both tubes is added $0.2 \mathrm{ml}$. of trichloracetic acid solution; the tubes are shaken carefully and placed in a boiling water bath for about three minutes.

The tubes are centrifuged at 3,000 r.p.m. for about five minutes.

These quantities are added to five ordinary test-tubes in sequence: $1 \mathrm{ml}$. water; $0.75 \mathrm{ml}$. water $+0.25 \mathrm{ml}$. iron solution; $0.50 \mathrm{ml}$. water $+0.50 \mathrm{ml}$. iron solution; $1.1 \mathrm{ml}$. supernatant fluid from the first Kahn tube; $1.1 \mathrm{ml}$. supernatant fluid from the second Kahn tube. To the first three tubes is added $0.1 \mathrm{ml}$. trichloracetic acid solution. To all tubes is added $5 \mathrm{ml}$. $o$-tolidine solution. To all tubes is added $0.1 \mathrm{ml}$. acid-peroxide solution.

The tubes are placed in a boiling water bath for 10 minutes. A golden-brown colour develops, the depth depending on the amount of iron present.

The tubes are cooled to room temperature and the depth of colour estimated in a photoelectric colorimeter using the first tube as the blank. 
In this work a Klett-Summerson colorimeter with the blue filter No. 42 (spectral range 400-465 $\mathrm{m}(\mathrm{l})$ was used. Calculation:

$$
\text { Calculation: } \frac{\left(\mathrm{P}_{1} \times 800+\mathrm{P}_{2} \times 400\right)}{\frac{2}{\left.\frac{\left(\mathrm{I}_{1} \times 4\right.}{2}+\mathrm{I}_{2} \times 2\right)}}=\frac{4 \mathrm{P}_{1}+2 \mathrm{P}_{2}}{2 \mathrm{I}_{1}+\mathrm{I}_{2}} \times 100=\mu \mathrm{g} . / 100 \mathrm{ml} \text {. }
$$

where $P_{1}=$ reading of test-tube No. $4(0.125 \mathrm{ml}$. plasma $)$

$\mathbf{P}_{2}=$ reading of test-tube No. $5(0.25 \mathrm{ml}$. plasma $)$

$\mathrm{I}_{1}=$ reading of test-tube No. $2(0.25 \mu \mathrm{g}$. iron)

$\mathbf{I}_{2}=$ reading of test-tube No. $3(0.50 \mu \mathrm{g}$. iron)

The purpose of using different amounts of both iron solution and plasma in the duplicate estimations included in one test is, first, to safeguard against contamination, which is a constant danger in all plasma iron estimations; secondly, to assure that sufficient $o$-tolidine is present to develop the full colour with larger amounts of iron; and, thirdly, to safeguard against incomplete precipitation of the plasma proteins or incomplete recovery of the proteiri-bound iron.

The number of tubes included in the test does not add to the labour involved, and any number of plasma iron estimations can be performed at one time, depending on the size of the water baths used.

\section{Total Iron-binding Capacity of the Plasma}

This is determined by the method suggested by Cartwright and Wintrobe (1949). After the collection of the blood as in the first step of the procedure described a supersaturating amount of iron is injected through the needle, and five minutes later another $3 \mathrm{ml}$. of blood collected from a different vein. The plasma iron of this blood is estimated with the first sample and is equal to the total iron-binding capacity of the patient's plasma.

In this investigation $7 \mathrm{ml}$. of ferrocalcium, "sandoz" (10 mg. of iron), were used in adult patients, and correspondingly smaller amounts in children.

\section{Results}

Correlation between Iron Content and Colour Development.--Fig. 1 shows that in the range from 0 to $1.0 \mu \mathrm{g}$. of iron the correlation between iron content and colorimeter reading is a straight line. With the quantities of plasma used in the test it is thus possible to estimate from 0 to $800 \mu \mathrm{g}$. of iron per $100 \mathrm{ml}$. of plasma, a range that covers all possible pathological values.

Specificity of the Reaction.-To a number of test-tubes were added $0.5 \mathrm{ml}$. of iron solution and $0.5 \mathrm{ml}$. of different solutions containing the following substances: $\mathrm{Al}, \mathrm{Ba}, \mathrm{Bi}, \mathrm{Br}, \mathrm{Ca}, \mathrm{Cd}, \mathrm{Co}, \mathrm{Cu}, \mathrm{Hg}, \mathrm{K}, \mathrm{Li}, \mathrm{Mg}, \mathrm{Mn}, \mathrm{Na}, \mathrm{Ni}, \mathrm{Pb}, \mathrm{Sb}, \mathrm{Sn}, \mathrm{Sr}, \mathrm{Zn}$, urea, uric acid, and creatine.

In those cases in which the concentration of the particular substance in human blood was known, the solution was adjusted to a value corresponding to about 10 times the value likely to be found in the blood. In no case did the readings of the colorimeter differ more than five divisions, which was within the error of the method. Iodine and bromine are known to produce a colour with $o$-tolidine, but the amounts necessary to interfere with the plasma iron estimation are far in excess of those found in the blood.

Oxalate, even in small amounts, completely inhibits the colour development. Oxalated blood cannot be used in this test, and if heparin is not available the iron 


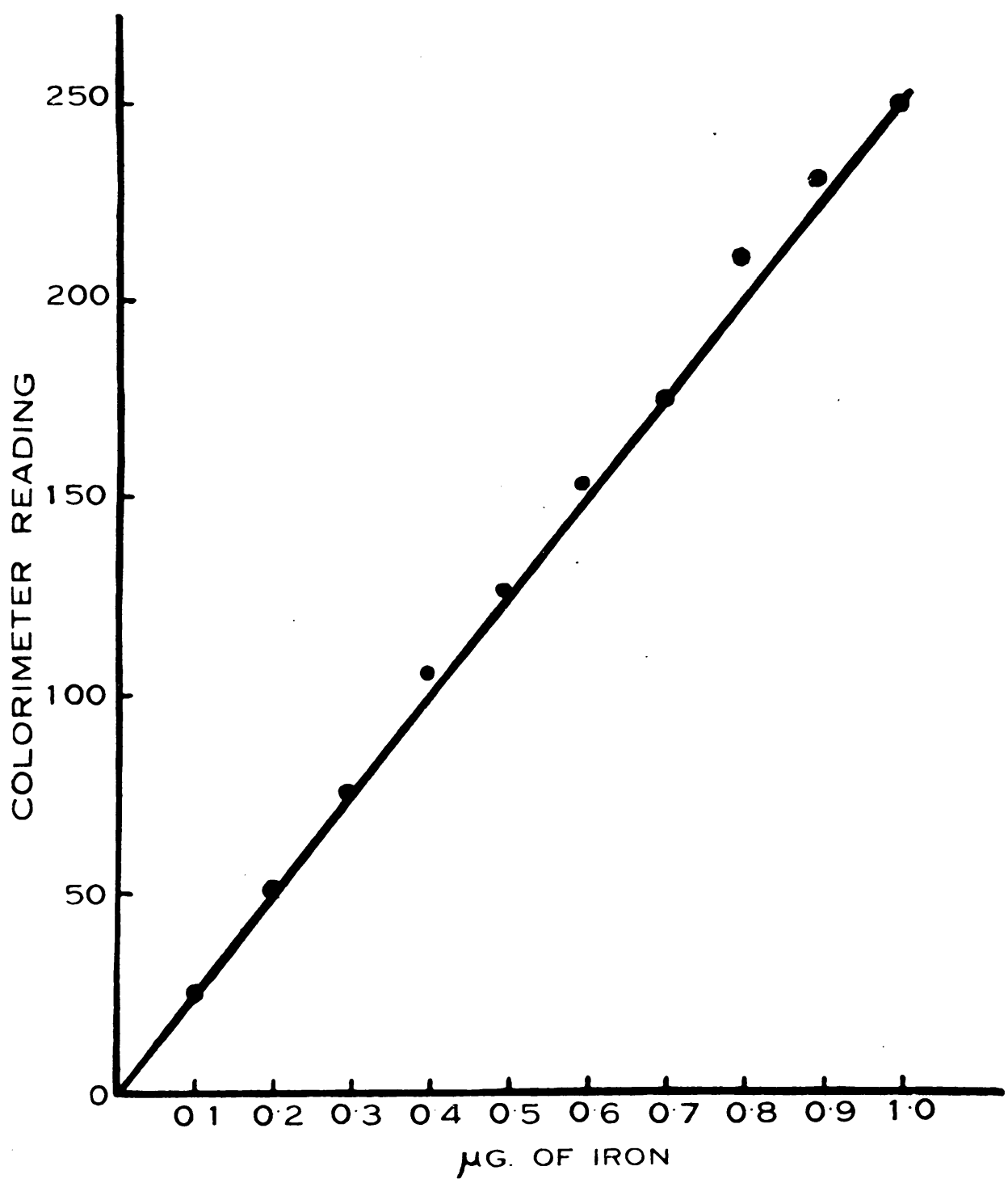

Fig. 1.-Correlation between iron content and colorimeter reading.

estimation must be done on serum which gives the same results as plasma. Serum is not used as a routine, as the loosening of the clot from the tube before centrifuging may introduce contamination.

Ascorbic acid is known to inhibit the $o$-tolidine test for blood in the urine (Barach and Pennock, 1940). In the case of plasma iron the amounts of ascorbic acid necessary to inhibit the colour development appreciably are of the order of $10 \mathrm{mg}$. per $100 \mathrm{ml}$. of plasma, values that again lie well above those found in the blood. 
Recovery of the Plasma Iron.-Kitzes, Elvehjem, and Schuette (1944), who also precipitated the proteins by heat and trichloracetic acid, found that a single washing gave full recovery of the liberated iron.

During the development of the present method washing of the precipitate with $o$-tolidine solution was first resorted to, but it was soon found that, due to the rise in the $p \mathrm{H}$ during the washing, some of the protein went into solution again and interfered with the colour development. Washing with trichloracetic acid solution was then tried, but two or even three washings did not increase the amount of iron recovered and only added to the manipulative difficulties and the danger of contamination.

Experiments aiming at the recovery of iron added to the plasma have also shown that the recovery is complete. Two examples are given in Table I.

TABLE I

Recovery of Iron Added to Plasma

\begin{tabular}{|c|c|c|c|c|c|}
\hline & $\begin{array}{l}\text { Tube } \\
\text { No. }\end{array}$ & Test Solution & $\begin{array}{l}\text { Colorimeter } \\
\text { Reading }\end{array}$ & $\begin{array}{l}\text { Total Iron } \\
\text { Found } \\
(\mu \mathrm{g} .)\end{array}$ & $\begin{array}{c}\text { Calculated } \\
\text { Value } \\
(\mu \mathrm{g} .)\end{array}$ \\
\hline (a) & $\begin{array}{l}1 \\
2 \\
3 \\
4 \\
5 \\
6 \\
7\end{array}$ & $\begin{array}{l}1 \mathrm{ml} \text {. water } \\
0.75 \mathrm{ml} \text {. water }+ \\
0.25 \mathrm{ml} \text {. iron solution } \\
0.50 \mathrm{ml} \text {. water }+ \\
0.50 \mathrm{ml} \text {. iron solution } \\
0.875 \mathrm{ml} \text {. water }+ \\
0.125 \mathrm{ml} \text {. plasma extract } \\
0.75 \mathrm{ml} \text {. water }+ \\
0.25 \mathrm{ml} \text {. plasma extract } \\
0.75 \mathrm{ml} \text {. water }+ \\
0.10 \mathrm{ml} \text {. plasma extract }+ \\
0.15 \mathrm{ml} \text {. iron solution } \\
0.75 \mathrm{ml} \text {. water }+ \\
0.15 \mathrm{ml} \text {. plasma extract }+ \\
0.10 \mathrm{ml} \text {. iron solution } \\
0.75 \mathrm{ml} \text {. water }+ \\
0.20 \mathrm{ml} \text {. plasma extract }+ \\
0.05 \mathrm{ml} \text {. iron solution }\end{array}$ & $\begin{array}{r}0 \\
56 \\
110 \\
36 \\
73 \\
68 \\
67 \\
70\end{array}$ & $\begin{array}{c}(0) \\
(0.25) \\
(0.50) \\
0.16 \\
0.33 \\
0.31 \\
0.30 \\
0.32\end{array}$ & $\begin{array}{l}0.28 \\
0.30 \\
0.31\end{array}$ \\
\hline (b) & $\begin{array}{l}1 \\
2 \\
3 \\
4 \\
5 \\
6 \\
7\end{array}$ & $\begin{array}{l}1 \mathrm{ml} \text {. water } \\
0.75 \mathrm{ml} \text {. water }+ \\
0.25 \mathrm{ml} \text {. iron solution } \\
0.50 \mathrm{ml} \text {. water }+ \\
0.50 \mathrm{ml} \text {. iron solution } \\
0.875 \mathrm{ml} \text {. water }+ \\
0.125 \mathrm{ml} \text {. plasma extract } \\
0.75 \mathrm{ml} \text {. water }+ \\
0.25 \mathrm{ml} \text {. plasma extract } \\
0.625 \mathrm{ml} \text {. water }+ \\
0.125 \mathrm{ml} \text {. plasma extract }+ \\
0.25 \mathrm{ml} \text {. iron solution } \\
0.75 \mathrm{ml} \text {. water }+ \\
0.125 \mathrm{ml} \text {. plasma extract }+ \\
0.125 \mathrm{ml} \text {. iron solution } \\
0.875 \mathrm{ml} \text {. water }+ \\
0.075 \mathrm{ml} \text {. plasma extract }+ \\
0.05 \mathrm{ml} \text {. iron solution }\end{array}$ & $\begin{array}{r}0 \\
75 \\
150 \\
63 \\
130 \\
145 \\
100 \\
52\end{array}$ & $\begin{array}{c}(0) \\
(0.25) \\
(0.50) \\
0.21 \\
0.43 \\
0.48 \\
0.333 \\
0.17\end{array}$ & $\begin{array}{l}0.47 \\
0.345 \\
0.17\end{array}$ \\
\hline
\end{tabular}


The Stability of the Colour.-To determine the stability of the colour the test tubes from one determination were kept at room temperature for 24 hours. The results are given in Table II.

TABLE II

THE STABILITY OF THE COLOUR

\begin{tabular}{c|c|c}
\hline Tube No. & $\begin{array}{c}\text { Colorimeter Reading } \\
\text { 1 Hour after Removal } \\
\text { from Water Bath }\end{array}$ & $\begin{array}{c}\text { Colorimeter Reading } \\
\text { 24 Hours Later }\end{array}$ \\
\hline 1 & 0 & 0 \\
2 & 65 & 65 \\
3 & 135 & 140 \\
4 & 50 & 50 \\
5 & 99 & 95 \\
\hline
\end{tabular}

Occasionally a fine brown precipitate separates out on prolonged standing. Placing the tubes in the water bath re-dissolves this precipitate, and, on cooling, the original colorimeter readings are again obtained.

TABLE III

ThE ACCURACY OF THE MethoD

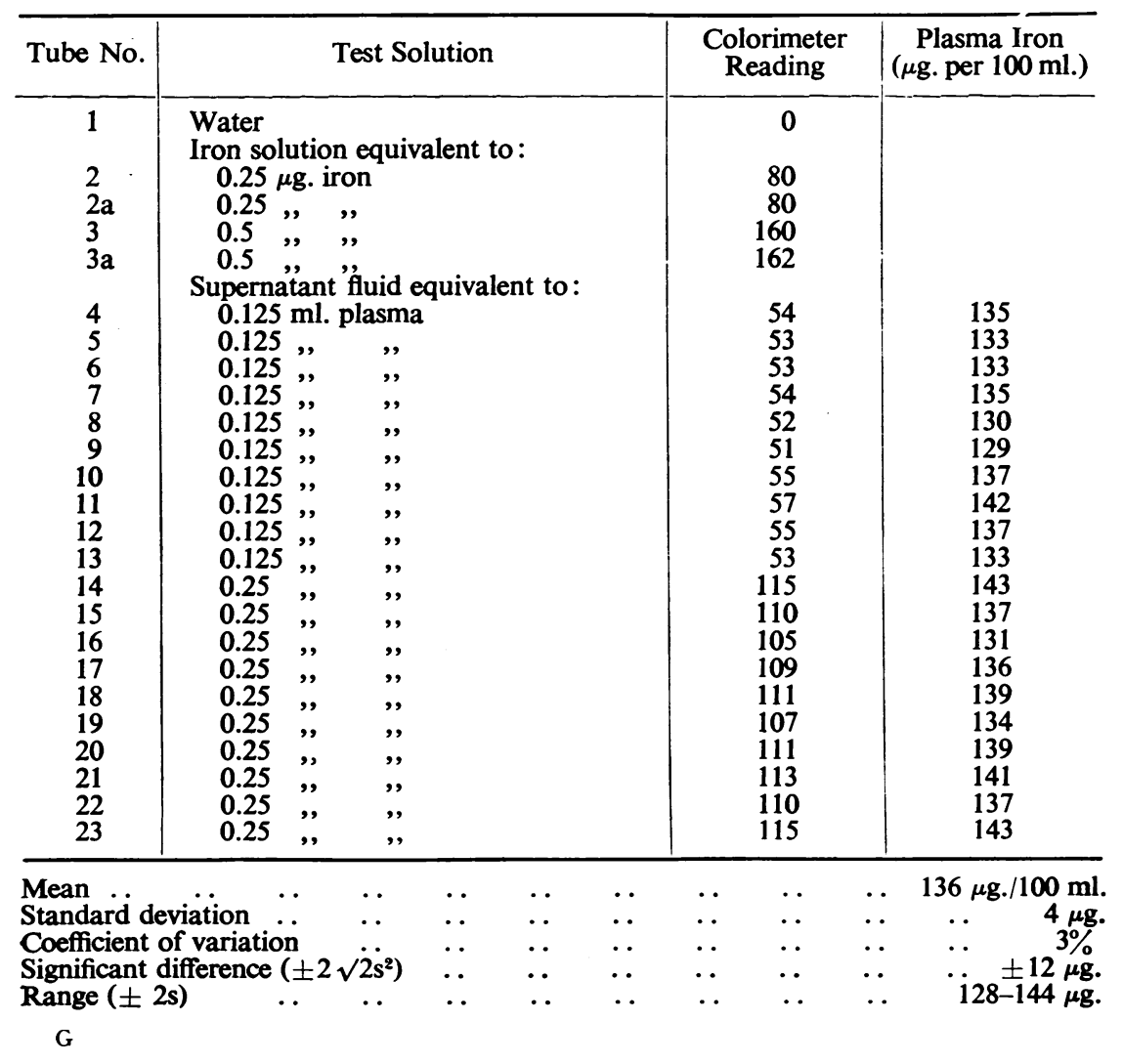


The Accuracy of the Method.-Twenty estimations were carried out simultaneously on the same plasma, ten on $0.25 \mathrm{ml}$. and ten on $0.5 \mathrm{ml}$. of plasma. The results are tabulated in Table III.

The taking of the blood from the patient, its transport, and centrifugation must add to the error of the method, as it must to all other methods, but the coefficient of variation is so small, expecially in view of the large normal range of plasma iron from 100 to $200 \mu \mathrm{g}$. per $100 \mathrm{ml}$., that the accuracy remains highly satisfactory.

Plasma Iron Values with the 0-Tolidine Method.--In 25 normal adults the plasma iron varied between 90 and $210 \mu \mathrm{g}$. per $100 \mathrm{ml}$. with a mean of $140 \mu \mathrm{g}$. The total iron-binding capacity fell between 300 and $400 \mu \mathrm{g}$. per $100 \mathrm{ml}$. with an average of $330 \mu \mathrm{g}$. The high plasma iron in pernicious anaemia and the low values in irondeficiency anaemia of infection have been similar to those reported in the literature.

Direct comparison with other methods was attempted. $\sim, \alpha^{1}$-Dipyridyl was not available. The potassium thiocyanate method of Tötterman (1949) was too insensitive in our hands or with our colorimeter to give readable results. The method of Vannotti and Delachaux (1949) gave the following values for their fraction $\mathrm{A}+\mathrm{B}$ on the same plasma, using $4 \mathrm{ml}$. of plasma for each test: $185 \mu \mathrm{g}$. and $162 \mu \mathrm{g}$. per $100 \mathrm{ml}$., whereas the $o$-tolidine method on this plasma gave the values of $171 \mu \mathrm{g}$. and $175 \mu \mathrm{g}$. per $100 \mathrm{ml}$.

Great difficulty was experienced in the precipitation of the proteins with the method of Vannotti and Delachaux. The impression remained that at least the first three of their plasma iron fractions were related to such precipitation difficulties, and the later work of Surgenor, Koechlin, and Strong (1949), Rath and Finch (1949), and Cartwright and Wintrobe (1949) would also indicate that such fractions are artifacts and of little pathological importance.

There seems little doubt that the $o$-tolidine method estimates the iron bound to the $\beta_{1}$-globulin of the plasma and therefore the iron of pathological significance.

\section{Summary}

A method is described for the estimation of plasma iron, including the total iron-binding capacity of the plasma, which is simple, rapid, and reliable.

The method is more sensitive than any previously described, requiring less than $1 \mathrm{ml}$. of plasma for a duplicate estimation.

The plasma iron values found by this test correspond to those obtained with other methods.

\section{REFERENCES}

Barach, J. H., and Pennock, L. L. (1940). J. Amer. med. Ass., 114, 640.

Cartwright, G. E., and Wintrobe, M. M. (1949). J. clin. Invest., 28, 86.

Kitzes, G., Elvehjem, C. A., and Schuette, H. A. (1944). J. biol. Chem., 155, 653.

Rath, C. E., and Finch, C. A. (1949). J. clin. Invest., 28, 79.

Ruttan, R. F., and Hardisty, R. H. M. (1912). Canad. med. Ass. J., 2, 995.

Surgenor, D. M., Koechlin, B. A., and Strong, L. E. (1949). J. clin. Invest., $28,73$.

Tötterman, L. E. (1949). Acta med. scand., Suppl. 230.

Vannotti, A., and Delachaux, A. (1949). Iron Metabolism and its Clinical Significance, trans. Pulay, E. London.

Zwarenstein, H. (1949). J. clin. Path., 2, 145. 